\title{
Male and Female Fertility of Loosestrife (Lythrum) Cultivars
}

\author{
Neil O. Anderson ${ }^{1}$ and Peter D. Ascher ${ }^{2}$ \\ Department of Horticultural Science, University of Minnesota, 1970 Folwell Avenue, St. Paul, MN 55108
}

Additional index words. Lythrum salicaria, Lythrum virgatum, Lythrum alatum, tristyly, heteromorphic self incompatibility, interspecific hybridization, seed set, germination, noxious weeds, Lythraceae, clonal integrity, $2 n$ gametes

\begin{abstract}
Male and female fertility, seed germination, and progeny fertility were used to determine cultivar fertility in species of Lythrum. One short-, 11 mid-, and six long-styled cultivars were included in this study. Duplicates of several cultivars from different nurseries and three unknown cultivars from Minnesota gardens were also collected. Plants from 17 Minnesota and one Wisconsin population of $L$. salicaria served as fertile male and/or female testers. Pollen stainability (usually $100 \%$ ) showed low levels of male gamete abortion. Pollen size within and among anther type varied widely; possible $2 n$ gametes were present in primarily the short- and mid-anther morphs. Seed production per capsule from legitimate crosspollinations, using cultivars as male parents with Minnesota or Wisconsin female testers, averaged $48 \pm 36$ across style morphs. Cultivars differed as males, as did anther morphs. With female fertility tests, seed set per capsule ranged from zero to 152 and averaged $54 \pm 40$ in legitimate pollinations (i.e., pollinations between stamen and styles of the same length). Seed set for other crosses showed similar trends. Only 'Morden Gleam' produced no seed with all legitimate pollinations, although illegitimate selfs or interspecific crosses produced seed. Seed from legitimate crosses of $L$. salicaria $\times$ cultivars had $30 \%$ to $100 \%$ germination. Common male and female parents within each legitimate crossing group were not significantly different. This study showed that the cultivars are highly fertile when used as male or female parents with wild purple loosestrife, native species ( $L$. alatum Pursh.), or other cultivars. Thus, cultivars grown in gardens could serve as pollen or seed sources for the continued spread of purple loosestrife. The implications of cultivar fertility, especially interspecific $F_{1}$ hybrids, is discussed in relation to the spread of noxious weeds in wetlands.
\end{abstract}

Eleven Lythrum spp., primarily diploid and distylous, are native to North America (Blackwell, 1970; Cody, 1978; Graham, 1975; Greenn, 1889; Koehne, 1885, 1903). L. alatum Pursh (=L. dacotanum Nieuwland), winged loosestrife, is the most cosmopolitan North American species, being distributed throughout the United States and Canada. Eurasian Lythrum naturalized in North America include L. salicaria L., L. virgatum L., L. hyssopifolia L., Peplis portula L. (=L. portula L.), and L. thymifolia L. (Blackwell, 1970; Koehne, 1903). Of these, L. salicaria and L. virgatum, both polyploid and tristylous, have colonized disturbed wetland habitats, frequently forming monospecific stands (Cutright, 1978). These two species are considered by North American taxonomists to be the same, because they differ for only a few minor diagnostic characteristics and intercross freely (Rendall, 1989; S. Graham, personal communication). In deference to this idea, we will refer to naturalized populations of $L$. salicaria and $L$. virgatum as purple loosestrife.

Due to multiple dispersal mechanisms, purple loosestrife has had many independent opportunities to form colonizing populations (Stuckey, 1980). However, it remained relatively obscure from 1814 until 1930, when it suddenly invaded pastures and wetland communities on its own accord (Barabe, 1951; Cutright, 1986; Louis-Marie, 1944). In contrast with its native habitat, where it usually comprises $1 \%$ to $4 \%$ of the vegetative cover, North American populations often form monospecific stands (Batra et al., 1986). Purple loosestrife currently occurs north of the 35th parallel in the contiguous United States (except Montana) and

Received for publication 8 Sept. 1992. Accepted for publication 9 Mar. 1993 University of Minnesota Agricultural Experiment Station Scientific Publication Series Paper no. 19,997. Support for this research was provided by a grant from the Legislative Commission on Minnesota Resources, conducted under the auspices of the Minnesota Dept. of Natural Resources, Division of Fisheries and Wildlife, Section of Ecological Services. The cost of publishing this paper was defrayed in part by the payment of page charges. Under postal regulations, this paper therefore must hereby be marked advertisement solely to indicate this fact.

${ }^{1}$ Postdoctoral Research Associate.

${ }^{2}$ Professor.
Canada, overlapping in distribution primarily with L. alatum. While L. alatum is more mesophytic than purple loosestrife, they occur in similar ecotopes. Despite ploidy differences, purple loosestrife ( $4 x$ and $6 x$ ) and L. alatum $(2 x)$ will intercross in natural settings (Levin, 1970). The presence of $2 n$ gametes in the pollen and eggs of Lythrum (Schoch-Bodmer, 1938) allows for the production of fertile hybrids. For instance, $n$ pollen $(2 x)$ from tetraploid $(2 n=4 x)$ cultivars, when deposited on stigmas of $L$. alatum producing unreduced eggs $(2 n=2 x)$, would result in progeny that would be tetraploid $(4 x)$. Several domesticated cultivars are the products of such interspecific hybridizations (Table 1).

The first reliable documentation of purple loosestrife in North America is 1814 (Pursh, 1814). Introduction of purple loosestrife in the conterminous United States occurred via the emptying of ship ballasts and importation as a domesticated ornamental crop (Cutright, 1978; 1986; Stuckey, 1980; Rawinski, 1982; Woehler and Henderson, 1986). Bee keepers and gardeners planted purple loosestrife, allowing it the opportunity to become established in settings (disturbed cultivated or natural) at multiple sites throughout the continental interior (Hayes, 1979; New York Times, 1932; Pellett, 1966; 1977; Rendall, 1989; Stuckey, 1980). From these sites, its seeds spread by means of air currents, flotation, fur of mink and muskrat, turtle shells, and dried mud on the feet of waterfowl (Stuckey, 1980). Clonal dissemination (stem cuttings or rhizomes) was aided by herbivores (muskrats) and human activity. The influx of European immigrants during the 19th century meant that North American settlers, accustomed to growing purple loosestrife as a garden perennial or seeing it naturalized across Europe, would be attracted to purchasing it should the seed industry offer it for sale. Mack (1991) provides documentation of the dissemination of purple loosestrife through the commercial seed trade. Nursery and seed trade catalogs listed purple loosestrife as early as 1829 (New York), 1833 (Massachusetts), and 1835 (Ohio). By 1932, vast populations dominated the vegetation along the Hudson River, providing a spectacular display of color throughout the summer (New York Times, 1932). Its popularity continued in the 
Table 1. Horticultural cultivars of Lythrum and their style morphs ( $\mathrm{S}=$ short, $\mathrm{M}=$ mid, and $\mathrm{L}=$ long) currently under cultivation in the United States and the number of accessions for each cultivar available for this study.

\begin{tabular}{|c|c|c|}
\hline Cultivars & Style morph(s) & $\begin{array}{c}\text { No. accessions } \\
\text { available }\end{array}$ \\
\hline \multicolumn{3}{|c|}{ Lythrum salicaria $L$} \\
\hline $\begin{array}{l}\text { var. tomentosum } \\
\text { var. roseum superbum }\end{array}$ & S,M,L & --- \\
\hline or Roseum Superbum & $\mathbf{M}$ & 1 \\
\hline var. gracilior & $\mathrm{M}, \mathrm{L}$ & --- \\
\hline Atropurpureum & Uuknown & --- \\
\hline Brightness & Unknown & --- \\
\hline $\begin{array}{l}\text { Firecandle, Fire Candle, } \\
\text { or Stichflamme }\end{array}$ & $\mathbf{M}$ & 1 \\
\hline \multicolumn{3}{|l|}{ Flashfire, Flash Fire, or } \\
\hline Feuerkerze $^{y}$ & $\mathrm{~L}$ & 2 \\
\hline Gypsy Blood or Zigeunerblut & $\mathbf{M}$ & 1 \\
\hline Happy $^{x}$ & $\mathrm{~L}$ & 1 \\
\hline Lady Sackville & Unknown & --- \\
\hline Loosestrife & M & 1 \\
\hline Mr. Roberts & Unknown & --- \\
\hline Robert $^{\mathrm{x}, \mathrm{w}}$ & $\mathrm{M}, \mathrm{L}$ & 5 \\
\hline Rose Gleam & Unknown & --- \\
\hline Rosy $\operatorname{Gem}^{\mathrm{x}}$ & Unknown & --- \\
\hline The Beacon & $\mathrm{S}$ & 1 \\
\hline Unknown & M,L & 3 \\
\hline \multicolumn{3}{|c|}{ Lythrum virgatum $L$. } \\
\hline Columbia Pink ${ }^{v}$ & Unknown & --- \\
\hline Dropmore Purple ${ }^{u}$ & $\mathrm{~L}$ & 1 \\
\hline Morden Gleam ${ }^{\mathbf{v}}$ & $\mathbf{M}$ & 1 \\
\hline Morden Pink $^{t}$ & M & 2 \\
\hline Morden Rose ${ }^{v}$ & $\mathbf{M}$ & 1 \\
\hline Pink Spires & $\mathbf{M}$ & 1. \\
\hline Purple Dwarf ${ }^{w}$ & M,L & 2 \\
\hline Purple Spires & $\mathbf{M}$ & 2 \\
\hline Rose Queen & $\mathrm{L}$ & 1 \\
\hline Rosyglow or Rosy Glow & Unknown & --- \\
\hline The Rocket & Unknown & --- \\
\hline
\end{tabular}

${ }^{\mathrm{Z}}$ Occasionally sold by nurseries as 'Feuerkerze'.

yOccasionally sold by nurseries as 'Stichflamme'.

${ }^{x}$ Disputed parentage; also classified as $L$. virgatum.

${ }^{w}$ Dwarf cultivars deriving their short stature from $L$. alatum in the pedigrees.

'Interspecific hybrid cultivars derived from the cross 'Morden Pink' $\times L$. alatum (winged loosestrife).

"Disputed parentage; also classified as $L$. salicaria.

tIncorrectly labeled as a "male-sterile" mutant of $L$. virgatum.

seed industry to the present. For instance, a recent survey of 50 retail packets of mixed wildflowers revealed that $10 \%$ contained purple loosestrife (see Hanna, 1989).

By the beginning of the 20th century, when flower gardening became increasingly popular, it became desirable to obtain clonally propagated loosestrife cultivars bred or selected for novel or superior phenotypes. Breeding programs in Europe and North America provided new cultivars for sale to nurseries. Historic planting records from Minnesota indicate that plantings at estates, public parks, or in wetlands included named cultivars. For example, in 1920, 775 Lythrum plants were planted by the City of Minneapolis Park System. These consisted of 600 Lythrum 'Superba' (probably L. salicaria var. roseum superbum) and 175
Lythrum 'Perry variety' (Minneapolis Park and Recreation Board, 1920). Similar cultivars were planted nearby in Ferndale Marsh (northeast of Browns Bay, Lake Minnetonka, Wayzata) during 1924-1929 (L. Kelly, personal communication). At the Glensheen Mansion (Duluth), one cultivar of purple loosestrife was planted in 1909 (Condon, 1909). Plantings of these cultivars survived for 70 years and naturalized at Birch Pond and Ferndale Marsh or remained in cultivation at the Glensheen Mansion until recent legislation necessitated their removal (L. Skinner, personal communication).

Morden cultivars ('Morden Gleam', 'Morden Pink', and 'Morden Rose') have remained popular with gardeners since the release of 'Morden Pink' in 1937. According to the Agriculture Canada Morden Research Station (Morden, Manitoba, Canada), 'Morden Pink' “. . .originated from a male-sterile mutant of $L$. virgatum. The varieties 'Morden Gleam' and 'Morden Rose' were developed by crossing 'Morden Pink' with select forms of the native Lythrum alatum. . .but tend to heavy seed production. ..." (Harp, 1957). This statement has caused considerable misunderstanding among nurseries and gardeners ever since (Rendall, 1989). A simple misreading has led everyone to believe that 'Morden Pink' is sterile. This is clearly not the case, as the report states that it originated from a male-sterile mutant; this does not imply that 'Morden Pink' itself is male-sterile. It is, obviously, female-fertile, because it was used in crosses whose progeny included 'Morden Gleam' and 'Morden Rose'. Nonetheless, current nursery catalogs still advertise 'Morden Pink' as a "sterile hybrid" that poses no threat to wetlands (Jackson and Perkins, 1992; White Flower Farm, 1992).

In response to the alarming spread of purple loosestrife $(\approx 8100$ ha infested by 1989), the Minnesota Legislature initiated regulatory legislation in 1987 to contain the spread of this noxious weed (Rendall, 1989). The Minnesota Dept. of Agriculture (MDA) labeled purple loosestrife a noxious weed and its sale was prohibited. In sympathy with the nursery industry, the MDA did not include $L$. virgatum at that time because it was thought that the cultivars of this species were sterile, and that they could be taxonomically distinguished from purple loosestrife. However, MDA inspectors had difficulty distinguishing between the two species when the plants were vegetative (Rendall, 1989). Thus, in Fall 1988, the MDA commissioner included both species and any combinations thereof (i.e., cultivars) as noxious weeds. Similar or less-restrictive legislation has now been enacted by other states, including Illinois, Indiana, Ohio, Washington, and Wisconsin (Cutright, 1986; The Ithaca Journal, 1989).

The Minnesota legislation caused considerable consternation among gardeners and the nursery industry (see Hanna, 1989; Horticulture, 1990), as the question of cultivar sterility remained unanswered. In 1989, we began analysis of the sterility issue using commercial cultivars of loosestrife. Lythrum spp. are heterostylous; therefore, populations typically consist of plants differing in style and anther lengths (Darwin, 1865; Koehne, 1903). Such spatial separation of anthers and styles enhances outcrossing via disassortative mating. There are distylous (two style morphs) and tristylous (three style morphs) species of Lythrum. The effectiveness of heterostyly in enhancing outcrossing is increased in Lythrum as it is linked with another reproductive barrier, self incompatibility (SI). With SI in operation, pollinations producing seed are those in which pollen is transferred from anthers that are the same height as the style (Fig. 1). Such pollinations are termed cross-compatible or "legitimate." All other combinations of outcrosses or selfs are termed cross- or self-incompatible or "illegitimate." On average, seed production in legitimate crosses is significantly greater than with illegitimate pollinations (Barlow, 1923). Ganders (1979) noted that tristyly is one of the most complicated reproductive barriers in existence. 


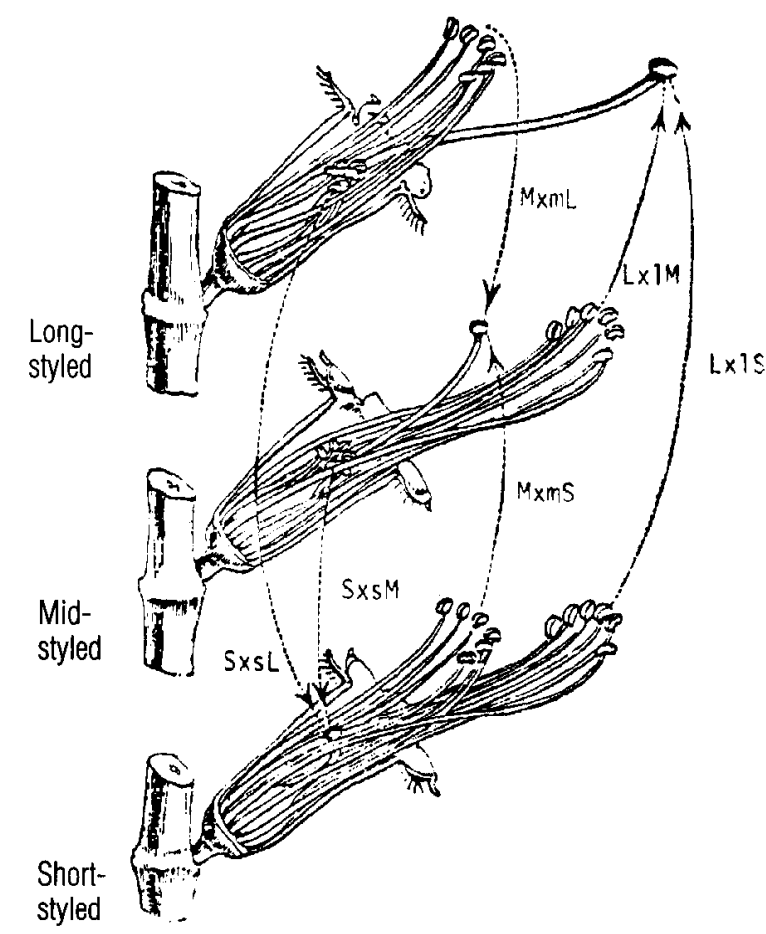

Fig. 1. Directions of legitimate pollinations producing full complements of seed in tristylous Lythrum salicaria (adapted from Darwin 1865, 1868). Arrows indicate direction of legitimate pollen flow; that is, the six compatible ("legitimate") combinations: $\mathrm{S} \times \mathrm{sM}$-short styles $\times$ short anthers (from a mid-styled plant), $\mathrm{S}$ $\times \mathrm{sL}, \mathrm{M} \times \mathrm{mS}, \mathrm{M} \times \mathrm{mL}, \mathrm{L} \times 1 \mathrm{~S}$, and $\mathrm{L} \times 1 \mathrm{M}$. The other 18 possible combinations are incompatible ("illegitimate"): selfs $-\mathrm{S} \times \mathrm{mS}, \mathrm{S} \times \mathrm{IS}, \mathbf{M} \times \mathrm{SM}, \mathbf{M} \times \mathrm{IM}, \mathrm{L} \times$ $\mathrm{sL}, \mathrm{L} \times \mathrm{mL}$; crosses $-\mathrm{S} \times \mathrm{mS}, \mathrm{S} \times \mathrm{mL}, \mathrm{S} \times \mathrm{IS}, \mathrm{S} \times \mathrm{IM}, \mathrm{M} \times \mathrm{sM}, \mathrm{M} \times \mathrm{sL}, \mathrm{M} \times \mathrm{IS}$, $\mathrm{M} \times \mathrm{IM}, \mathrm{L} \times \mathrm{sM}, \mathrm{L} \times \mathrm{sL}, \mathrm{L} \times \mathrm{mS}$, and $\mathrm{L} \times \mathrm{mM}$.

The objective of our research was to evaluate cultivar fertility (male and female), seed germination (progeny viability), and progeny fertility. Male fertility was assessed using pollen stainability and seed set/capsule, using as male parents, cultivars, and fertile purple loosestrife testers as female parents from naturalized Minnesota and Wisconsin populations. Female fertility (seed set/ capsule) was assessed using legitimate cross pollinations with fertile male testers of purple loosestrife from Minnesota and Wisconsin populations. Seed germination (viability) and fertility of the progeny were also examined.

\section{Materials and Methods}

Environmental conditions. Plants were grown to flowering in $305-\mathrm{cm}^{3}$ pots in glasshouses at St. Paul, Minn. (lat. $45^{\circ} \mathrm{N}$ ), maintained at $24 \pm 5 \mathrm{C}$ days and $17 \pm 2 \mathrm{C}$ nights. The potting medium (Baccto Prof. Planting Mix, Mich. Peat Co., Houston, Texas) was a commercially available soilless mix. Mineral nutritional requirements were monitored using biweekly soil tests; standard insecticidal/fungicidal practices were followed. To induce flowering, longday photoperiods were maintained using natural day lengths (21 Mar. to 21 Sept.) or supplemental lighting (high-intensity discharge lamps, 0600-2200 HR) throughout the remainder of each calendar year.

Plant material. Rooted cuttings or divisions of 18 Lythrum cultivars available commercially were obtained from North American nurseries or breeding programs (Table 1). In several instances, clones of the same cultivars were obtained from different nursery sources. The number of different accessions available for the same cultivar are included in Table 1. Three cultivars were collected from Minnesota gardens and were labeled as "unknown." All cultivars were tested for male/female fertility, seed germination, and progeny fertility.

In several instances, cultivars were dug and shipped without pruning and possessed numerous seed capsules. These seed capsules were harvested, counted, and seeds were germinated to produce open-pollinated progeny for fertility analysis.

Representative samples of individual plants from 17 populations of purple loosestrife in Minnesota and one population from Wisconsin were cloned (rooted cuttings) and grown in the glasshouse. The populations had no previous record of disturbance from eradication efforts (hand-pulling, cutting, burning, flooding, or herbicide applications). Individuals from each population were assigned coded numbers (e.g., S-02-21) to designate the Lythrum species $(\mathrm{S}=L$. salicaria), 02 (population site number), and 21 (plant no. 21 within the population). Colonizing populations included Black Dog Prairie (S-05, Dakota County, T27N, R20W, Sec.26), Minnesota Landscape Arboretum (S-10, Carver County, T117N, R23W, Sec.36), Jim McKee Prairie (S-11, Ramsey County, T29N, R22W, Sec.24), industrial site (S-12, Washington County, T29N, R22W, Sec.24), prairie (S-17, Freeborn County, T102N, R20W, Sec. 1), Mississippi River (S-30, Hennepin County, T29N, R23W, Sec.5), and Lavinia (S-32, Beltrami County, T147N, R33W, Sec.25). Established populations were from the following locations: Fort Snelling State Park (S-01, Hennepin County, T27N, R20W, Sec.12), Taft Park (S-02, Hennepin County, T27N, R20W, Sec.35), Springbrook Nature Center (S-03, Anoka County, T30N, R24W, Sec.2), Maplewood Nature Center (S-04, Ramsey County, T29N, R22W, Sec.24), Ferndale Marsh (S-06, Hennepin County, T117N, R22W, Sec.5), Pigs Eye Lake (S-07, Ramsey County, T27N, R20W, Sec. 15), Wirth Lake (S-08, Hennepin County, T29N, R24W, Sec.20), White Bear Lake (S-34, Ramsey County, T29N, R22W, Sec.22), Winona Lake Park (S-35, Winona County, T18N, R11W, Sec.18), BirchPond (S37, Hennepin County, T29N, R24W, Sec.29), and Green Bay, Wis. (S-33, Brown County, T24N, R20E).

Male fertility. Pollen stainability and legitimate cross-pollinations were used to assess male fertility of the cultivars. For pollen stainability, pollen from each of two anther types on each cultivar were collected, placed on glass microscope slides, and stained with aniline blue in $80 \%$ propionic acid (E.B. Smith, personal communication). Living pollen grain cytoplasm, when examined under a light microscope, stains a dark blue, whereas aborted pollen (lacking cytoplasm) does not pick up the stain. Five microscope fields with $n>20$ pollen grains/field were counted for the number of stained and unstained pollen grains. Percent of pollen grains that were stainable was calculated from these counts.

For legitimate pollinations, as a test for male fertility of cultivars, plants from the naturalized populations were selected at random and screened a priori to ensure that they were female-fertile. Unopened flowers (before anthesis) were emasculated and pollinated with the appropriate legitimate pollen (Fig. 1) when the stigmas were receptive. Cross numbers $(90-104$, etc.) were assigned to each pollination performed using the year (90 for 1990, etc.) and cross number within years $(104$, etc.). Seed set per capsule was recorded; there were $n=$ 10 pollinations per cross. To ensure that the seed produced was viable and resulted in fertile progeny, seed germination tests were conducted. Progeny derived from these crosses were also examined for male fertility using the same tests.

Seed set was analyzed using analysis of variance (ANOVA) and mean separations (pollinations were the experimental units). All crosses were analyzed for normality. A normal distribution curve line was fitted to the data and tests for skewness, kurtosis, goodness of fit (using Yates' correction for continuity) were performed. 
Female fertility. Seed production was used as a gauge of female fertility of the cultivars. Pollination procedures followed those outlined for male fertility seed set. Outcross seed set of the cultivars or open-pollinated progeny was recorded from legitimate cross-pollinations ( $n=3$ /genotype) using pollen from plants selected at random from the naturalized populations. If all of these pollinations failed to produce seed with a particular female, illegitimate pollinations (selfs or crosses) were also performed. Cultivars were also legitimately cross-pollinated with each other to simulate the potential for intercultivar crossing within gardens or nurseries. Such pollinations were categorized, based on the species in each pedigree, into within- and between-species groups. Seed set was analyzed with the same statistics used for male fertility.

Seed germination. Seeds were sown on 19-21 Nov. 1990 in plug trays. The seed germination environment was a glasshouse mist bench $(21 / 21 \mathrm{C}$, day/night) with natural short-day photoperiods. Each plug tray was filled with Baccto soil mix. The arrangement for each experiment ( $L$. salicaria $\times$ cultivars, cultivars $\times L$. salicaria, and cultivars $\times$ cultivars) was a completely randomized design with three replications (10 seeds/replication) per crosspollination. Seeds were placed on top of the soil and were considered germinated when the radicle emerged through the outer seed coat. Percent germination was calculated subsequently. Before statistical analysis, all data were tested for conformity to the assumptions of ANOVA or were transformed by the arcsin squareroot (Sokal and Rolf, 1981; Stephens and Bougourd, 1988).

To ensure a balanced design, crosses producing $\mathrm{n} \geq 30$ seeds/ pollination were chosen at random within each female or male fertility experiment. From each cross, 30 undamaged seeds were chosen at random within each cross for germination analysis. Six legitimate, outcross pollination groups (Fig. 1) were analyzed using seed from population $\times$ cultivar crosses. Replications within each group were chosen based on common male or female parents. With cultivar $\times$ population fertility tests, crosses within the legitimate crossing groups were categorized based on the number of parents in common (one or two) between reciprocal crosses. Cultivar $\times$ cultivar pollinations were categorized based on withinor between-species groups.

\section{Results}

Clones of the horticultural cultivars obtained from various nurseries often were not morphologically identical. The most extreme case was 'Robert', where all five clones differed for at least one morphological marker. For example, four of the clones (data not shown) differed in the shape of the leaf base, leaf length leaf color, flower petal length, and style morph (Table 1). Additionally, only one clone matched the correct description of this plant (dwarf with dark-green foliage). This indicates that clonal integrity has not been maintained.

Male fertility. Pollen stainability was high (Table 2); in most instances, all pollen stained. In all cases except one (short anthers of 'Rose Queen', average $=30 \%$ stainability), mean pollen stainability was $>50 \%$. Representatives of cloned cultivars obtained from separate nurseries did not necessarily show the same level of pollen stainability; i.e., 'Feuerkerze' $\# 1$ average $=100 \%$, 'Feuerkerze' \#2 average $=54 \%$ for short anthers, etc. (Table 2). There is no evidence to suggest appreciable male sterility for the tested cultivars. This result disproves the assumption that 'Morden Pink' is a male-sterile mutant (Cutright, 1986). Pollen stainability for progeny derived from the crosses performed exhibited similar levels of pollen stainability (data not shown). As reported previously (Barlow, 1923), pollen size varied between anther type
Table 2. Percent pollen stainability (average \pm SD) for commercial cultivars of purple loosestrife evaluated for fertility.

\begin{tabular}{|c|c|c|c|}
\hline \multirow[b]{2}{*}{ Cultivar } & \multicolumn{3}{|c|}{ Anther length (\%) } \\
\hline & Short & Mid & Long \\
\hline Dropmore Purple & $60 \pm 9$ & $58 \pm 22$ & \\
\hline Feuerkerze \#1 & $100 \pm 0$ & $81 \pm 9$ & \\
\hline Feuerkerze \#2 & $54 \pm 15$ & $64 \pm 5$ & \\
\hline Happy & $62 \pm 22$ & $76 \pm 9$ & \\
\hline Loosestrife $^{\mathrm{z}}$ & $100 \pm 0$ & & $100 \pm 0$ \\
\hline Morden Gleam & $79 \pm 11$ & & $96 \pm 7$ \\
\hline Morden Pink \#1 & $65 \pm 9$ & & $92 \pm 8$ \\
\hline Morden Pink \#2 & $100 \pm 0$ & & $100 \pm 0$ \\
\hline Morden Rose & $53 \pm 22$ & & $74 \pm 13$ \\
\hline Purple Dwarf \#1 & $100 \pm 0$ & & $100 \pm 0$ \\
\hline Purple Dwarf \#2 & $70 \pm 6$ & $75 \pm 10$ & \\
\hline Pink Spires & $100 \pm 0$ & & $100 \pm 0$ \\
\hline Purple Spires \#1 & $100 \pm 0$ & & $100 \pm 0$ \\
\hline Purple Spires \#2 & $100 \pm 0$ & & $100 \pm 0$ \\
\hline Robert \#1 & $100 \pm 0$ & $59 \pm 5$ & \\
\hline Robert \#2 & $69 \pm 12$ & & $100 \pm 0$ \\
\hline Robert \#3 & $78 \pm 21$ & & $100 \pm 0$ \\
\hline Robert \#4 & $100 \pm 0$ & & $100 \pm 0$ \\
\hline Robert \#5 & $100 \pm 0$ & & $100 \pm 0$ \\
\hline Rose Queen & $30 \pm 8$ & $51 \pm 10$ & \\
\hline Roseum Superbum & $100 \pm 0$ & & $100 \pm 0$ \\
\hline Stichflamme & $78 \pm 4$ & & $79 \pm 5$ \\
\hline The Beacon & & $69 \pm 21$ & $100 \pm 0$ \\
\hline Unknown \# $1^{y}$ & $100 \pm 0$ & & $100 \pm 0$ \\
\hline Unknown \#2 & $100 \pm 0$ & $100 \pm 0$ & \\
\hline Unknown \#3 & $100 \pm 0$ & $100 \pm 0$ & \\
\hline Zigeunerblut & $100 \pm 0$ & & $100 \pm 0$ \\
\hline
\end{tabular}

$\overline{\text { zSold by nurseries as a Lythrum salicaria cultivar, but identified only as }}$ 'Loosestrife'.

yUnknown cultivars were collected from Minnesota gardens. The actual cultivars could not be determined using morphological markers.

(average diameters were 20 pm-small, 28 pm-mid, and $38 \mu \mathrm{m}-$ large). Large pollen grains (potentially $2 n$ gametes) were present in primarily the short- and mid-anther morphs (data not shown).

Seed production per capsule from legitimate pollinations, using cultivars as male parents with Minnesota or Wisconsin purple loosestrife female testers, averaged $48 \pm 36$ across style morphs. Seed set/capsule ranged from zero to 143 (Table 3), a range similar to that reported for legitimate pollinations in wild populations of purple loosestrife (Barlow 1913; Darwin 1868). In general, the trend was for lower seed set per capsule for short styles $\times$ short anthers (range $0-138$, average $=41 \pm 36$ ) than for mid styles $\times$ mid anthers (range $0-136$, average $=50 \pm 36$ ) or long styles $\times$ long anthers (range $0-143$, average $=56 \pm 35$ ). However, the variability in seed set, regardless of anther morph, produced standard deviations almost as large as the means. Cultivars were significantly different as males $(\mathrm{F}=3.4, P=0.0002)$, as were anther morphs $(\mathrm{F}$ $=10.2, P<0.00001)$. There was no significant cultivar $\times$ anther morph interaction $(\mathrm{F}=0.52, P=0.998)$.

Female fertility. Seed set per capsule ranged from zero to 152 and averaged $54 \pm 40$ for all legitimate pollinations of cultivar $\times$ purple loosestrife populations. Seed set on short-styled individuals ranged from 0 to 51, while mid-styled cultivars produced 0 to 152 seeds and long-styled had 0 to 142 . Average seed set values for mids $(57 \pm 44)$ and longs $(53 \pm 33)$ were similar, although shorts (26 \pm 19$)$ were less productive. This difference may be due to the small sample size $(\mathrm{n}=1)$ of short-styled cultivars ('The Beacon'). 
Table 3 . Average \pm SD seed production per capsule from legitimate crosspollinations ( $\mathrm{n}=10$ pollinations per cross) between horticultural purple loosestrife cultivars (male parents) and Minnesota or Wisconsin Lythrum salicaria populations (female fertile, tester parents) as a measurement of male fertility.

\begin{tabular}{|c|c|c|c|}
\hline \multirow[b]{2}{*}{ Cultivar } & \multicolumn{3}{|c|}{ Seed set per capsule (mean \pm SD) } \\
\hline & $\begin{array}{l}\text { Short anthers } \\
\times \text { short styles }\end{array}$ & $\begin{array}{l}\text { Mid anthers } \\
\times \text { mid styles }\end{array}$ & $\begin{array}{l}\text { Long anthers } \\
\times \text { long styles }\end{array}$ \\
\hline Dropmore Purple & $23 \pm 28$ ef $^{2}$ & $28 \pm 28 d^{2}$ & \\
\hline Feuerkerze \#1 & $44 \pm 32 a-f$ & $38 \pm 39 \mathrm{~cd}$ & \\
\hline Feuerkerze \#2 & $24 \pm 30 \mathrm{~d}-\mathrm{f}$ & $59 \pm 31 \mathrm{a}-\mathrm{c}$ & \\
\hline Happy & $52 \pm 25 a-e$ & $83 \pm 25$ a & \\
\hline Loosestrife & $31 \pm 37 \mathrm{c}-\mathrm{f}$ & & $62 \pm 31 a-c^{2}$ \\
\hline Morden Gleam & $62 \pm 47 \mathrm{ab}$ & & $43 \pm 37 b c$ \\
\hline Morden Pink \#1 & $21 \pm 22$ ef & & $46 \pm 27 a-c$ \\
\hline Morden Pink \#2 & $49 \pm 40 \mathrm{a}-\mathrm{f}$ & & $72 \pm 37 a b$ \\
\hline Morden Rose & $20 \pm 28 \mathrm{f}$ & & $43 \pm 27 b c$ \\
\hline Purple Dwarf \#1 & $41 \pm 42 b-f$ & & $60 \pm 43 a-c$ \\
\hline Purple Dwarf \#2 & $19 \pm 24 \mathrm{f}$ & $24 \pm 31 d$ & \\
\hline Pink Spires & $47 \pm 32 a-f$ & & $37 \pm 32 c$ \\
\hline Purple Spires \#1 & $20 \pm 31 \mathrm{f}$ & & $54 \pm 40 a-c$ \\
\hline Purple Spires \#2 & $60 \pm 36 a-c$ & & $61 \pm 35 a-c$ \\
\hline Robert \#1 & $55 \pm 38 \mathrm{a}-\mathrm{c}$ & $44 \pm 42 \mathrm{~cd}$ & \\
\hline Robert \#2 & $47 \pm 37 a-f$ & & $55 \pm 36 a-c$ \\
\hline Robert \#3 & $54 \pm 44 a-d$ & & $47 \pm 37 a-c$ \\
\hline Robert \#4 & $35 \pm 35 \mathrm{~b}-\mathrm{f}$ & & $62 \pm 26 a-c$ \\
\hline Robert \#5 & $23 \pm 29 \mathrm{~d}-\mathrm{f}$ & & $65 \pm 44 a-c$ \\
\hline Rose Queen & $38 \pm 36 b-f$ & $24 \pm 31 d$ & \\
\hline Roseum Superbum & $47 \pm 30 a-f$ & & $52 \pm 30 a-c$ \\
\hline Stichflamme & $44 \pm 34 \mathrm{a}-\mathrm{f}$ & & $60 \pm 52 a-c$ \\
\hline The Beacon & & $50 \pm 33 b-d$ & $77 \pm 32 \mathrm{a}$ \\
\hline Unknown \#1 & $56 \pm 39 a-c$ & & $67 \pm 14 a-c$ \\
\hline Unknown \#2 & $47 \pm 44 \mathrm{a}-\mathrm{f}$ & $60 \pm 41 a-c$ & \\
\hline Unknown \#3 & $73 \pm 17 \mathrm{a}$ & $75 \pm 8 \mathrm{ab}$ & \\
\hline Zigeunerblut & $36 \pm 40 \mathrm{~b}-\mathrm{f}$ & & $52 \pm 26 a-c$ \\
\hline Average & $41 \pm 36$ & $50 \pm 36$ & $56 \pm 35$ \\
\hline
\end{tabular}

${ }^{\bar{z}}$ Mean separations within columns (anthers), Fisher's least significant difference (LSD) test, $P \leq 0.05$.

However, ANOVA indicated that cultivars $(\mathrm{F}=1.57, P=0.14)$, style morphs $(\mathrm{F}=1.27, P=0.295)$, and their interaction $(\mathrm{F}=0.12$, $P=1.0)$ were not statistically significant. Seed production for cultivar $\times$ cultivar (between and within species groups) crosses showed similar trends (range 0-132, average $=44 \pm 37$ ).

No cultivar in this experiment was absolutely female-sterile, because some seed set occurred in one or more replications (pollinations) in all cultivars. Legitimate pollinations involving 'Morden Gleam' did not produce seed; however, selfing 'Morden Gleam' and interspecific hybridization with L. alatum did result in seed set (data not shown). In addition, open-pollinated seed (from selfing or crossing in the nursery) was collected from this cultivar.

A histogram of seed set distribution showed that 30 to 59 seed set was the mode (Fig. 2A). Tests for normality in outcross seed production were performed; two-tailed tests showed skewness to be significant $(t=-1.606, P=0.0106)$, while kurtosis was not $(t=$ $-0.113, P=0.372$ ). The goodness-of-fit test for normality, using Yates' correction for continuity, was significant $(\mathrm{G}=12.92, P=$ 0.0048 ). Thus, seed production does not fit a criterion for normality, being significantly skewed towards zero seed set.

Female fertility levels of progeny generated from crossing cultivars with purple loosestrife populations, crosses between and within cultivar species groups, and open-pollinated seed from
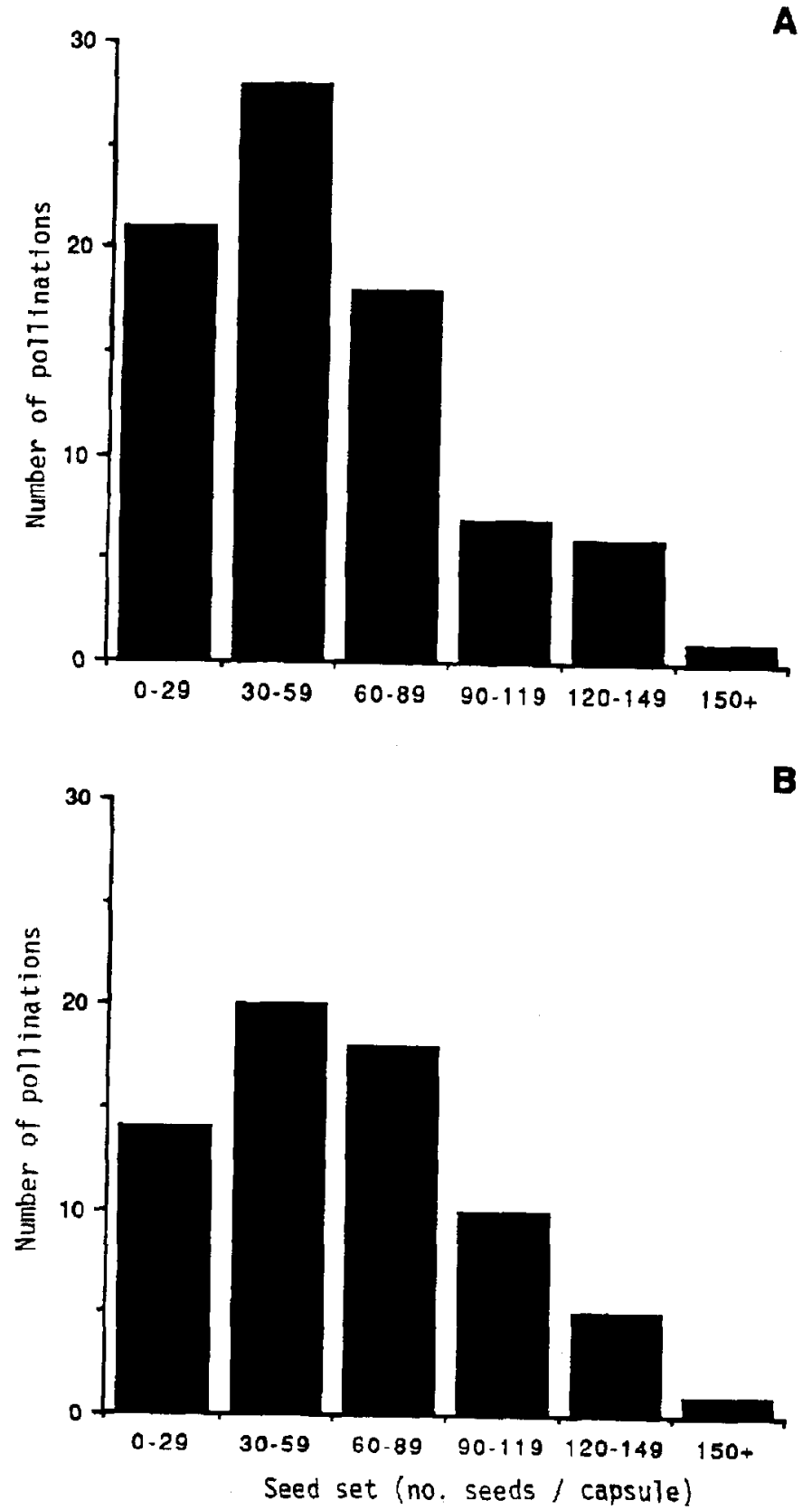

Fig. 2. Histogram of seed set from legitimate, outcross pollinations between (A) horticultural cultivars of purple loosestrife (female parents) and Minnesota populations of Lythrum salicaria (male parents) and (B) open-pollinated progeny derived from commercial horticultural cultivars of Lythrum.

cultivars grown in commercial nurseries were similar to the seed set exhibited by the parents. Due to the large amount of fertility data, only a representative sample is included here. Open-pollinated seed collected from 'Morden Gleam', 'Roseum Superbum', and 'The Beacon' were germinated, producing fertile mid- and long-styled progeny. Seed set per capsule ranged from 0 to 155 for mid styles and 0 to 236 for long styles. On average, mid-styled seed production $(48 \pm 38)$ was lower $(\mathrm{F}=18.5, P=0.0001)$ than for long styles $(94 \pm 43)$. Genotypes $(F=1.2, P=0.312)$ and their interaction with style morph $(\mathrm{F}=0.31, P=0.99)$ were not significant. Tests for normality of seed set distribution were similar to those found for the cultivars; i.e., the test for skewness ( $t=0.504, P=0.0437)$ was significant, while tests for kurtosis $(t$ $=-0.37, P=0.2628)$ and the goodness-of-fit test for normality $(\mathrm{G}$ $=0.26, P=0.607$ ) were not. Seed production (Fig. $2 \mathrm{~B}$ ) also 
Table 4. Average \pm SD percent seed germination from six legitimate crossing groups of Lythrum salicaria $\times$ cultivar fertility tests.

\begin{tabular}{lccccc}
\hline \hline & \multicolumn{2}{c}{ Common male parent } & & \multicolumn{2}{c}{ Common female parent } \\
\cline { 2 - 3 } \cline { 5 - 5 } $\begin{array}{l}\text { Crossing } \\
\text { group }\end{array}$ & Cross no. & $\begin{array}{c}\text { Germination }(\%) \\
\text { (mean } \pm \mathrm{sd})\end{array}$ & Cross no. & $\begin{array}{c}\text { Germination (\%) } \\
\text { (mean } \pm \mathrm{sd})\end{array}$ \\
\hline $\mathrm{L} \times \mathrm{Lm}^{z}$ & $90-30$ & $30 \pm 14 \mathrm{~b}^{\mathrm{y}}$ & $90-31$ & $93 \pm 5 \mathrm{a}^{\mathrm{y}}$ \\
& $90-32$ & $97 \pm 5 \mathrm{a}$ & $90-33$ & $90 \pm 0 \mathrm{a}$ \\
$\mathrm{L} \times \mathrm{Ls}$ & $90-34$ & $87 \pm 5 \mathrm{a}$ & $90-35$ & $67 \pm 17 \mathrm{a}$ \\
& $90-36$ & $87 \pm 5 \mathrm{a}$ & $90-35$ & $87 \pm 9 \mathrm{a}$ \\
$\mathrm{M} \times \mathrm{Ml}$ & $90-37$ & $73 \pm 12 \mathrm{~b}$ & $90-38$ & $55 \pm 16 \mathrm{c}$ \\
& $90-39$ & $100 \pm 0 \mathrm{a}$ & $90-40$ & $60 \pm 8 \mathrm{~b}$ \\
$\mathrm{M} \times \mathrm{Ms}$ & $90-41$ & $80 \pm 16 \mathrm{a}$ & $90-42$ & $97 \pm 5 \mathrm{a}$ \\
& $90-43$ & $80 \pm 0 \mathrm{a}$ & $90-42$ & $93 \pm 5 \mathrm{a}$ \\
$\mathrm{S} \times \mathrm{Sm}$ & $90-44$ & $50 \pm 8 \mathrm{~b}$ & $90-45$ & $62 \pm 9 \mathrm{a}$ \\
& $90-46$ & $80 \pm 8 \mathrm{a}$ & $90-47$ & $77 \pm 9 \mathrm{a}$ \\
$\mathrm{S} \times \mathrm{Sl}$ & $90-48$ & $87 \pm 12 \mathrm{a}$ & $90-49$ & $78 \pm 13 \mathrm{a}$ \\
& $90-50$ & $100 \pm 0 \mathrm{a}$ & $90-51$ & $100 \pm 0 \mathrm{a}$
\end{tabular}

$\overline{{ }^{\bar{z}} \text { Uppercase letters denote the style morph and lowercase letters are used }}$ for the anther morphs. S,s = short; $M, m=$ mid; $L, 1=$ long.

yMean separations within legitimate crossing groups, Fisher's least significant difference (LSD) test, $P \leq 0.05$ ( I.SD $=2.5 .5$ ).

exhibited a distribution similar to that found for the cultivars, with the highest seed set in the 30 to 59 range.
Seed germination. Purple loosestrife $\times$ cultivar legitimate crossing groups had $30 \%$ to $100 \%$ germination (Table 4); with most crosses, germination exceeded $50 \%$. There were no instances of $0 \%$ germination. Average percent germination for the six legitimate crossing groups were $78 \%(\mathrm{~L} \times 1 \mathrm{M}), 82 \%(\mathrm{~L} \times 1 \mathrm{~S}), 72 \%(\mathrm{M} \times \mathrm{mL})$, $88 \%(\mathrm{M} \times \mathrm{mS}), 67 \%(\mathrm{~S} \times \mathrm{sM})$, and $89 \%(\mathrm{~S} \times \mathrm{sL})$. Common male and female parents within each legitimate crossing group responded similarly $(\mathrm{F}=0.51, P=0.477)$. However, differences for crosses within groups $(\mathrm{F}=36.8, P<0.00001)$ and between legitimate crossing groups $(\mathrm{F}=5.9, P=0.0003)$ were highly significant.

Average percent seed germination of cultivar $\times$ purple loosestrife legitimate crosses ranged from $21 \%$ to $100 \%$ (Table 5). Results for reciprocal crosses were not statistically significant $(\mathrm{F}=0.3, P=$ 0.5847). However, differences for pollinations within crossing groups were significant $(\mathrm{F}=2.2, P=0.0053)$. While there were differences in percent germination between legitimate crossing groups, results from these two studies (Tables 4 and 5) showed that legitimate crossing group, style morph, or use of cultivars as males or females in combination with purple loosestrife populations did not absolutely interfere with the production of viable seeds.

Legitimate cultivar $\times$ cultivar pollinations between and within species groups (Table 6) were slightly lower in average germination $(10 \%$ to $87 \%)$ than when cultivars were crossed with purple loosestrife populations (Tables 4 and 5). However, there were no cases of inviable seed ( $0 \%$ germination), indicating that crosses

Table 5. Average \pm SD percent seed germination of selected crosses (with one or two parents in common) for analyzing seed germination of legitimate cultivar $\times$ Lythrum salicaria crosses and reciprocals.

\begin{tabular}{|c|c|c|c|c|c|}
\hline \multirow[b]{2}{*}{$\begin{array}{l}\text { Legitimate } \\
\text { crossing } \\
\text { group }^{z}\end{array}$} & \multirow[b]{2}{*}{ Cross no. } & \multirow[b]{2}{*}{$\begin{array}{l}\text { Germination }(\%) \\
\quad(\text { mean } \pm \mathrm{SD})\end{array}$} & \multicolumn{3}{|c|}{ Reciprocal crosses } \\
\hline & & & $\begin{array}{l}\text { Legitimate } \\
\text { crossing } \\
\text { group }^{2}\end{array}$ & Cross no. & $\begin{array}{c}\text { Germination }(\%) \\
(\text { mean } \pm \mathrm{SD})\end{array}$ \\
\hline \multicolumn{6}{|c|}{ Both parents in common } \\
\hline \multirow[t]{5}{*}{$\mathrm{L} \times \mathrm{MI}$} & $90-110$ & $73 \pm 24 a^{y}$ & $\mathrm{M} \times \mathrm{Lm}$ & $90-111$ & $70 \pm 18 a^{y}$ \\
\hline & $90-112$ & $70 \pm 14 a$ & & $90-113$ & $77 \pm 5 \mathrm{a}$ \\
\hline & $90-114$ & $50 \pm 22 \mathrm{a}$ & & $90-115$ & $71 \pm 26 a$ \\
\hline & $90-116$ & $21 \pm 12 b$ & & $90-117$ & $73 \pm 17$ a \\
\hline & $90-118$ & $70 \pm 22 a$ & & $90-119$ & $56 \pm 9 \mathrm{a}$ \\
\hline \multirow[t]{4}{*}{$\mathbf{M} \times \mathbf{L m}$} & $90-120$ & $53 \pm 17 a$ & $\mathbf{L} \times \mathbf{M l}$ & $90-121$ & $77 \pm 33 a$ \\
\hline & $90-124$ & $100 \pm 0 \mathrm{a}$ & & $90-125$ & $77 \pm 9 \mathrm{a}$ \\
\hline & $90-126$ & $27 \pm 25 b$ & & $90-127$ & $53 \pm 9 \mathrm{a}$ \\
\hline & $90-128$ & $57 \pm 20 a$ & & $90-129$ & $33 \pm 9 b$ \\
\hline $\mathrm{M} \times \mathrm{Sm}$ & $90-122$ & $77 \pm 17$ a & $\mathrm{S} \times \mathrm{Ms}$ & $90-123$ & $54 \pm 21 \mathrm{a}$ \\
\hline \multicolumn{6}{|c|}{ One parent in common (cultivar) } \\
\hline \multirow[t]{2}{*}{$\mathrm{L} \times \mathrm{Sl}$} & $90-130$ & $90 \pm 8 \mathrm{a}$ & $\mathrm{M} \times \mathrm{Lm}$ & $90-131$ & $80 \pm 8 a$ \\
\hline & $90-146$ & $67 \pm 12 a$ & & $90-147$ & $83 \pm 9 a$ \\
\hline \multirow[t]{2}{*}{$\mathrm{L} \times \mathrm{Ml}$} & $90-132$ & $53 \pm 24 a$ & $\mathrm{M} \times \mathrm{Lm}$ & $90-133$ & $50 \pm 27 a$ \\
\hline & $90-150$ & $93 \pm 9 a$ & & $90-151$ & $73 \pm 20 a$ \\
\hline \multirow[t]{5}{*}{$\mathbf{M} \times \mathrm{Sm}$} & $90-134$ & $63+24 a$ & $\mathrm{~L} \times \mathrm{Ml}$ & $90-135$ & $57 \pm 33 a$ \\
\hline & $90-140$ & $90 \pm 0 a$ & & $90-141$ & $87 \pm 9 a$ \\
\hline & $90-152$ & $50 \pm 22 a$ & & $90-153$ & $50 \pm 22$ a \\
\hline & $90-138$ & $65 \pm 21 a$ & $\mathrm{~S} \times \mathrm{Ms}$ & $90-139$ & $87 \pm 12 a$ \\
\hline & $90-142$ & $97 \pm 5 \mathrm{a}$ & & $90-143$ & $90 \pm 0 \mathrm{a}$ \\
\hline \multirow[t]{4}{*}{$\mathbf{M} \times \mathbf{L m}$} & $90-136$ & $70 \pm 16 a$ & $\mathrm{~L} \times \mathrm{Ml}$ & $90-137$ & $53 \pm 12 a$ \\
\hline & $90-148$ & $90 \pm 14 a$ & & $90-149$ & $60 \pm 24 a$ \\
\hline & $90-154$ & $70 \pm 14 \mathrm{a}$ & & $90-155$ & $63 \pm 5 a$ \\
\hline & $90-144$ & $60 \pm 0 a$ & $\mathrm{~S} \times \mathrm{Ms}$ & $90-145$ & $53 \pm 12 a$ \\
\hline
\end{tabular}

${ }^{\mathrm{z}}$ Uppercase letters denote the style morph and lowercase letters are used for the anther morphs. $\mathrm{S}, \mathrm{s}=$ short; $\mathrm{M}, \mathrm{m}=$ mid; L, I = long

'Mean separations between crossing groups and number of parents in common, Fisher's least significant difference (LSD) test, $P \leq 0.05$ (LSD $=63$ ). 
between cultivars in a nursery or garden setting could produce viable progeny. Species groups $(\mathrm{F}=0.6, P=0.6759)$ and crosses within groups $(\mathrm{F}=0.52, P=0.8251)$ showed no significant differences for percent germination.

\section{Discussion}

The apparent lack of clonal integrity (differing style morphs, Table 1) with at least one loosestrife cultivar ('Robert') has disturbing implications for consumers and for the control of this noxious weed in natural environs. If clonal integrity cannot be maintained by commercial propagators, due to the lack of easily identifiable and environmentally stable phenotypic markers, it seems unreasonable to expect that MDA weed inspectors would be able to differentiate between cultivars and purple loosestrife. Complex morphological measurements of flowering loosestrife can distinguish among cultivars (Ottenbright, 1991), although undertaking such measurements is time-consuming. In addition, the morphological traits of the cultivars are similar to those of naturalized purple loosestrife populations (unpublished data).

Transient types of male sterility in most plant species can be induced by environmental variations. Microsporogenesis is particularly sensitive to temperature, light, or nutritional stress (Allard, 1960). However, functional anthers existed and pollen was shed at anthesis throughout the two years of this experiment with loosestrife. Using the generally accepted $50 \%$ stainable pollen as an indicator of male fertility, only the short anthers of 'Rose Queen' ( $30 \%$ stainability) would be potentially male-sterile (Table 2).

Table 6. Average \pm SD percent seed germination studies of legitimate Lythrum cultivar $\times$ cultivar crosses, classified according to species in the pedigree of each cultivar.

\begin{tabular}{|c|c|c|c|}
\hline Species & $\begin{array}{c}\text { Legitimate } \\
\text { crossing group }^{2}\end{array}$ & Cross no. & $\begin{array}{l}\text { Germination }(\%) \\
\quad(\text { mean } \pm \text { SD })\end{array}$ \\
\hline \multicolumn{4}{|c|}{ Within species groups } \\
\hline \multirow[t]{10}{*}{ L. salicaria } & $\mathrm{S} \times \mathrm{Ms}$ & $90-100$ & $80^{y} \pm 8$ \\
\hline & $\mathrm{M} \times \mathrm{Sm}$ & $90-95$ & $50 \pm 0$ \\
\hline & & $90-97$ & $40 \pm 8$ \\
\hline & $\mathrm{M} \times \mathrm{Lm}$ & $90-94$ & $60 \pm 29$ \\
\hline & & $90-98$ & $80 \pm 14$ \\
\hline & & $90-99$ & $87 \pm 12$ \\
\hline & $\mathrm{L} \times \mathrm{Ml}$ & $90-91$ & $20 \pm 14$ \\
\hline & & $90-92$ & $43 \pm 9$ \\
\hline & & $90-93$ & $57 \pm 17$ \\
\hline & & $90-96$ & $77 \pm 17$ \\
\hline \multirow[t]{2}{*}{ L. virgatum } & $\mathbf{M} \times \mathbf{L m}$ & $90-101$ & $43 \pm 17$ \\
\hline & & $90-102$ & $44 \pm 16$ \\
\hline
\end{tabular}

L. alatum

Between species groups

L. salicaria $\times$

$\begin{array}{llll}\text { L. virgatum } & \mathrm{M} \times \mathrm{Sm} & 90-104 & 63 \pm 12 \\ & & 90-105 & 70 \pm 8 \\ & \mathrm{M} \times \mathrm{Lm} & 90-106 & 30 \pm 8 \\ & \mathrm{~L} \times \mathrm{M} 1 & 90-103 & 23 \pm 5 \\ & & 90-107 & 10 \pm 14 \\ \text { L. salicaria } \times \text { L. alatum } & \mathrm{L} \times \mathrm{M} 1 & 90-108 & 40 \pm 24 \\ \text { L. virgatum } \times \text { L. alatum } & \mathrm{L} \times \mathrm{Ml} & 90-109 & 23 \pm 26\end{array}$

${ }^{\mathrm{z}}$ Uppercase letters denote the style morph and lowercase letters are used for the anther morphs. S, $\mathrm{s}=$ short; $\mathrm{M}, \mathrm{m}=$ mid; $\mathrm{L}, \mathrm{l}=$ long.

y Means were not statistically significant $(P=0.6759)$.

${ }^{\mathrm{x}}$ All possible crossing combinations are illegitimate.
From an evolutionary standpoint, however, it only takes one viable male gamete to fuse with an egg to make a seed, so $>0 \%$ pollen stainability could effect fertilization. 'Rose Queen' produced satisfactory seed set when used as a male tester in legitimate crosses with purple loosestrife individuals (average $=38$ seeds/ capsule, Table 3 ). Such seed production was as high or higher than that from short anthers from the remaining cultivars included in the study. Thus, $50 \%$ stainability appears to be a liberal gauge of male fertility for Lythrum cultivars.

Reasons for the lack of seed set in legitimate crosses involving 'Morden Gleam' merit further attention. Obviously this cultivar is not male-sterile, due to the high levels of pollen stainability (79\%-short anthers, 96\%-long anthers, Table 2) and seed production when used as a male parent (Table 3). Lack of seed set as a female tester suggests that this cultivar is female-sterile, as gardeners and the nursery industry insist. However, seed from open-pollination in a nursery (producing fertile progeny, see Fig. 2B), selfing, or interspecific crossing with L. alatum, demonstrated that this cultivar was not female-sterile. Yet, it is puzzling that it does not produce seed when legitimately crossed with tester plants. 'Morden Gleam' is an interspecific hybrid (Table 1) between tristylous L. virgatum and distylous L. alatum originating from an illegitimate pollination; i.e., 'Morden Pink' (mid-styled) $\times$ L. alatum (either short- or long-styled). Therefore, its mid style and short/long anther lengths may differ from tristylous purple loosestrife such that the incompatibility identity and flower morphology are no longer synchronized. The occurrence of zero seed set in legitimate combinations involving other cultivars may be due to similar differences in anther/style lengths, indicating either widespread interspecific hybridization in Minnesota and Wisconsin purple loosestrife populations or an erosion of the tristyly SI system (Ganders, 1979). Loss of a style morph in heterostyled populations is not unusual. Loss of a morph in tristyly results in distyly, while a similar loss in distyly produces a monomorphic system. Dimorphic populations of purple loosestrife (usually missing the short style) occur frequently among colonizing populations (Eckert and Barrett, 1989).

While female sterility would be highly desirable in loosestrife cultivars, it was not found in any genotype included here. Seed set per capsule (Fig. 2A) was as high or higher than reported previously for purple loosestrife individuals (Darwin, 1868) and there was no statistical difference between style morphs for seed production. The additional lack of $0 \%$ seed germination for any legitimate crosses examined (Tables 4 and 5) confirms that seed production would inevitably lead to fertile progeny, provided the proper germination conditions existed and niches were available in the ecotope. Female sterility-as a lack of or impaired ovule development affecting seed set or germination (viability) — does not exist in loosestrife cultivars and must be distinguished from the operative SI system that can give the appearance of female sterility.

Given the predominance of viable male gametes and female fertility in all loosestrife cultivars examined in this study, the question naturally arises as to why the nursery industry and gardeners alike have almost unanimously touted these cultivars as sterile. We propose that the assumptions of sterility have been based largely on misinformation or a lack of knowledge regarding the reproductive system operating in Lythrum. Observations of a consistent lack of seed production by cultivars over years and locations does not justify the conclusion of cultivar sterility. While it may indicate the potential for sterility to exist, failure to produce seed may also be circumstantial. For instance, a nursery may specialize in several loosestrife cultivars that have the same style morph. If the nursery is geographically isolated from other Lythrum 
pollen sources, seed production may not be possible because no legitimate pollinations could occur (Fig. 1). The only alternative is for illegitimate pollinations to effect fertilization. If the SI system is "tight," such that selfing or illegitimate crosses never produce seed, the cultivars will have a "sterile" phenotype.

While "open-pollinated" seed was obtained from several cultivars grown in nursery container production areas, it is highly probable that such seeds would never have had the chance to grow to maturity in a nursery. First, the conventional use of preemergent herbicides would eliminate any seedling that did germinate. Second, those seeds that might have been transported to areas in the nursery without preemergent herbicide treatment would most likely be removed by hand-weeding, without recognizing them and/or the application of broad-spectrum, nonselective herbicides. Home gardeners might use similar options or resort to mulching or hand-pulling to eliminate unwanted, volunteer seedlings. Third, proper germination requirements (especially light) may also be limiting factors preventing seedling germination. Thus, the claims that no seedlings have ever been seen under selected cultivated settings are, in all probability, true, but this only testifies to the effectiveness of weed control practices and does not remove the potential existence of fertility and seed production.

Cultivars derived from interspecific hybridization between purple loosestrife and L. alatum (Table 1)—e.g., 'Columbia Pink', 'Morden Gleam', dwarf forms of 'Robert', and 'Morden Rose'could serve as hybrid bridges for the transfer of evolutionarily adaptive traits from North American species into weedy Eurasian taxa. Cultivars could hybridize readily with purple loosestrife populations, adding genes for local adaptation to the developing weeds. While introgressive hybrids may already exist in naturalized populations, garden cultivars would hasten the rate of introgression because they already occupy niches in cultivated settings (gardens or nurseries). Similar cases have been reported previously (Anderson, 1949) where introgressive hybridization is favored due to the influence of humans in habitat disturbance and the cultivation of interspecific hybrids.

Although seed set distributions of horticultural cultivars were significantly skewed (Fig. 2), results of this study have demonstrated clearly that the cultivars are highly fertile, producing viable seeds and fertile progeny when crossed as male or female with wild purple loosestrife populations, L. alatum, or other cultivars. Thus, Lythrum cultivars grown in gardens could serve as pollen or seed sources, thereby promoting the continued spread of purple loosestrife. While this has unfortunate implications for the sale of loosestrife cultivars, it is necessary that the nursery industry and gardeners alike become environmentally responsible and disavow cultivation of such cultivars. We concur with the legislation drafted by Minnesota and other states that prohibits distribution and sale of these fertile cultivars.

\section{Literature Cited}

Allard, R.W. 1960. Principles of plant breeding. Wiley, New York. Anderson, E. 1949. Introgressive hybridization. Wiley, New York. Barabe, R. 1951. Progress report on the eradication of purple loosestrife (Lythrum salicaria L.) in Quebec. Proc. 4th Mtg., E. Sec., Natl. Weed Committee, Ottawa, Canada. 6-8 Nov. 1950. p. 83-90.

Barlow, N. 1913. Preliminary notes on heterostylism in Oxalis and Lythrum. J. Genet. 3:53-65.

Barlow, N. 1923. Inheritance of the three forms in trimorphic species. J. Genet. 13(2):133-145.
Batra, S.W.T., D. Schroeder, P.E. Boldt, and W. Mendl. 1986. Insects associated with purple loosestrife (Lythrum salicaria L.) in Europe. Proc. Ent. Soc. (Washington) 88(4):748-759.

Blackwell, W.H. 1970. The Lythraceae of Ohio. Ohio J. Sci. 70:346-352.

Cody, W.J. 1978. The status of Lythrum alatum (Lythraceae) in Canada. Can. Field Naturalist 92:74-75.

Condon, C.A. 1909. Planting list for Tischer Creek Park. Glensheen Mansion, Duluth, Minn.

Cutright, N.J. 1978. Purple loosestrife: Beautiful exotic, or unwanted weed? Wis. Natural Resources 2(5):26-27.

Cutright, N.J. 1986. Regulation of purple loosestrife by states in the Midwest. Proc. N. Cent. Weed Control Conf. 41:123-125.

Darwin, C.R. 1865. On the sexual relations of the three forms of Lythrum salicaria. J. Linn. Soc. Bot. 8:169-196.

Darwin, C.R. 1868. On the character and hybrid-like nature of the offspring from the illegitimate unions of dimorphic and trimorphic plants. Proc. Linn. Soc. Bot. 10:393-437.

Eckert, C.G. and S.C.H. Barrett. 1989. The effect of population dynamics and life-history traits on genetic drift at style morph loci in tristylous populations. Amer. J. Bot. 76:146. (Suppl. 6.) (Abstr.).

Ganders, F.R. 1979. The biology of heterostyly. N.Z.J. Bot. 17:607-635.

Graham, S.A. 1975. Taxonomy of the Lythraceae in the southeastern United States. SIDA 6(2):80-103.

Greenn, E.L. 1889. The genus Lythrum in California. Pittonia 2:11-13.

Hanna, J. 1989. Purple invader. Fed. Ontario Naturalists, Summer. p. 20-22, 36.

Harp, H.F. 1957. The Morden Lythrums. Weekly Note. n.p. Morden Research Station.

Hayes, B. 1979. Purple loosestrife-the wetlands honey plant. Amer. Bee J. 119:382-383.

Horticulture. 1990. The loosestrife saga continues. Horticulture. Jan. 1990. p. 6-7. Jackson and Perkins. 1992. Spring garden collection catalog. Jackson and Perkins, Medford, Ore. p. 2.

Koehne, E. 1885. The Lythraceae of the United States. Bot. Gaz. 10:268-277.

Koehne, E. 1903. Lythraceae. In: A. Engler (ed.). Das Pflanzenreich. W. Engelmann, Leipzig 4(17):1-78.

Levin, D.A. 1970. Assortative pollination in Lythrrum. Amer. J. Bot. 57:1-5.

Louis-Marie, P. 1944. La Salicaire dans le Quebec. Inst. Agr. d'Oka, Prov. Quebec, Canada.

Mack, R.N. 1991. The commercial seed trade: An early disperser of weeds in the United States. Econ. Bot. 45(2):257-273.

Minneapolis Park and Recreation Board. 1920. Forestry Nursery Record 30 Oct.

New York Times. 1932. Find 'Long Purples' in Interstate Park. Visitors to Harriman Preserve along Hudson River are attracted by the plant. Flower is an 'immigrant.' Lythrum salicaria in full blossom now in marshes and streams through the valley. New York Times, Sunday, 21 Aug., p. 19.

Ottenbright, K.A. 1991. The distribution, reproductive biology, and morphology of Lythrum species, hybrids, and cultivars in Manitoba. MS Thesis, Univ. of Manitoba, Winnipeg, Canada.

Pellett, M. 1966. Purple loosestrife, colorful honey plant Amer. Bee J. 106:134-135.

Pellet, M. 1977. Purple loosestrife spreads down river. Amer. Bee J. 117:214-215.

Pursh, F. 1814. Flora Americae Septentrionalis; or, a systematic arrangement and description of the plants of North America. White, Cochrane and Co., London.

Rawinski, T.J. 1982. The ecology and management of purple loosestrife (Lythrum salicaria L.) in central New York. MS Thesis, Cornell Univ., Ithaca, N.Y.

Rendall, J. 1989. The Lythrum story: A new chapter. Minn. Hort. 117(2):22-24.

Schoch-Bodmer, H. 1938. Die Veraenderlichkeit der Pollengroesse bei Lythrum salicaria L. Flora Jena 133:69-110.

Sokal, R.R. and F.J. Rolf. 1981. Biometry. Freeman, San Francisco.

Stephens, J.P. and S.M. Bougourd. 1988. Inbreeding depression and the outcrossing rate in natural populations of Allium schoenoprasum L. (wild chives). Heredity 60:257-261.

Stuckey, R.L. 1980. Distributional history of Lythrum salicaria (purple loosestrife) in North America. Bartonia 47:3-20.

The Ithaca Journal. 1989. Flower is pretty and also a problem; Plant is damaging delicate wetlands. The Ithaca Journal, Aug. 18:7A. Ithaca, N.Y.

White Flower Farm. 1992. The best and brightest. Spring 1992, Litchfield, Conn. p. 39.

Woehler, E.E. and R.A. Henderson. 1986. Distribution of purple loosestrife in the Midwest. Proc. N. Cent. Weed Control Conf. 41:129. (Abstr.). 